\title{
Zihinsel Yetersizliği Olan Çocuğa Sahip Ebeveynlerin Problem Çözme Becerileri ile Yaşam Doyumlarının İncelenmesi $^{1}$
}

\author{
DOI: $10.26466 /$ opus.787019 \\ * \\ Feray Başgöze* - Mücahit Kağan** \\ *Uzm. Psiklojik Danışman, Milli Eğitim Bakanlığı, Erzincan/ Türkiye \\ E-Posta: feraybasgoze@gmail.com \\ ORCID: $\underline{0000-0003-2822-2492}$ \\ **Prof. Dr., Erzincan Binali Yıldırım Üniversitesi, Erzincan/ Türkiye \\ E-Posta: mkagan24@gmail.com \\ ORCID: 0000-0003-1983-5748
}

\begin{abstract}
Öz
Bu araştırmada, zihinsel yetersizliği olan çocuğa sahip ebeveynlerin problem çözme becerileri ile yaşam doyumlarının incelenmesi amaçlanmıştır. Araştırmada, kullanılan model ilişkisel tarama yöntemidir. Katılımcılar Erzincan İli'nde bulunan Özel Eğitim Mesleki Ĕğitim ve Özel Eğitim İş Uygulama Okulları'nda eğitimine devam eden zihinsel yetersizliği olan 138 çocuğun ebeveyninden oluşmaktadır. Araştırmanın verileri Kişisel Bilgi Formu, Yaşam Doyumu Ölçeği ve Yetişkinlerde Problem Çözme Ölçeği kullanılarak toplamıştır. Elde edilen verilerin analizinde normallik varsayımının karşılandı̆̆ durumlarda parametrik analiz yöntemlerinden Pearson Korelasyon Analizi, Bağımsız Örneklem $t$ Testi ve Regresyon analizi, normallik varsayımının karşılanmadığı durumlarda parametrik olmayan testlerden Kruskal Wallis H ve Mann Whitney U Testi kullanılmıştır. Araştırma elde edilen bulgularda, zihinsel yetersizliği olan çocuğa sahip ebeveynlerin yaşam doyumu ve problem çözme becerileri arasında pozitif yönde manidar bir ilişki tespit edilmiştir. Bununla birlikte ebeveynlerin yaşam doyumu ve problem çözme becerilerinin; cinsiyete, çocuklarının tanısına ve çocuklarının aldığı özel eğitim süresine göre farklılaştı̆̆̊ buna karşın yaş, eğitim düzeyi ve çocuğ un birden fazla engelinin olması gibi değ işkenlerin ise yaşam doyumu ve problem çözme becerileri ile ilişkili olmadığı bulunmuştur. Ayrıca zihinsel yetersizliği olan çocuğa sahip ebeveynlerin yaşam doyumlar üzerinde, problem çözme becerisinin, çocuklarının aldığ̊ özel eğitim süresinin ve çocuklarının tanı durumunun anlamlı birer yordayıcı olduğu görülmüştür.
\end{abstract}

Anahtar Kelimeler: Zihinsel yetersizlik, problem çözme, yaşam doyumu

\footnotetext{
${ }^{1}$ Bu çalışma 1. Yazarın yüksek lisans tezinden üretilmiştir.
} 


\title{
Investigation Of Problem Solving Skills And Life Satisfaction Of Parents Having Children With Mental Retardation
}

\begin{abstract}
The aim of this study is to investigate the problem solving skills and life satisfaction of parents having children with mentalretardation. The research was designed in a correlational survey method The sample of the study consisted of the parents having 138 children having mentally handicapped at Special Education Vocational Training and Special Education Practice School in province of Erzincan. The data was collected through Personal Information Form, The Satisfaction with Life Scale and Problem Solving Scale for adults. In the analysis process, when the normality assumptions are provided, parametric tests like Pearson Correlation Analysis, Independent Sample t Test and Regression Analysis. Have been used, otherwise nonparametric tests like Kruskal Wallis H and Mann Whitney U Test have been used. When the results of the study have been evaluated, it has been determined that there is a positive and significant relationship between life satisfaction of parents having children with mental retardation and problem solving skills. However; life satisfaction and problem solving skills of parents having children with mental retardation become different according to gender, diagnosis of their children and how long their children have had special education. It has been detected that there is no relationship between some variables such as age, educational status, the child with multiple disabilities and their life satisfaction, also their problem solving skills. Inaddition, problem solving skills, special education period and diagnosis of their children are significant predictors of life satisfaction of parents having children with mental retardation.
\end{abstract}

Keywords: School, leadership, servant leadership 


\section{Giriş}

Aile, toplumun temelini oluşturan ve sosyal bir kurum olarak varlığını sürdüren öğelerin başında yer almaktadır. Öyle ki bu kurum toplumun en küçük yapı taşı olarak kabul edilir ve bireylerin yaşamında vazgeçilmez bir öneme sahiptir. Aile parçası olduğu toplumun kültürünü, gelenek ve göreneklerini, değer yargılarını yansıtarak kendi içinde spesifik bir düzenle çevresiyle iletişim ve etkileşim içerisinde bulunan bir kurumdur. Evlilik ve kan bağı ile oluşan bu kurum karı- koca, çocuklar ve kardeşler arasındaki ilişkilerin meydana getirdiği toplumun en küçük birimidir (Nazlı, 2001).

Hayatın rutin akışı içerisinde aile birliğini oluşturmak bireyleri mutlu k1lan mühim olaylardandır. Kurulan aile birliğinin ardından aileye dahil olan yeni bir bebek ise ailenin genişlemesine ve aile içi ilişkilerde pek çok değişikliğe neden olabilmektedir. Yeni bir çocuğa sahip olmanın ve onu yetiştirmenin ebeveynlerin yaşayabileceği en değerli ve aynı zamanda da en zor tecrübelerden biri olduğu söylenebilir. Çocuk yetiştirmek çiftlerde maddi ve manevi olarak büyük izler bırakır. Bununla birlikte ailenin sosyal yapısının da çocuğun üzerinde etkileri olabilir. Çünkü çocuğun ilk sosyal deneyimlerini kazandığı yer olan aile çocukların gelişiminde hem yol gösterici hem de kuralları öğretici bir rol üstlenir (Friel ve Friel, 2003).

Her aile çocuğunun sağllklı ve normal bir hayat sürmesini ister ve çocuğu dünyaya gelmeden önceki beklentisi de bu doğrultudadır. Nitekim ebeveynler için engeli olan bir çocuğa sahip olmak ise yaşamlarında karşılaşabilecekleri en zor ve yıpratıcı deneyimlerden biri olabilir. Engelli bir çocuğun doğumu birçok aile için acı ve şaşkınlık verici bir durum olabilir. Dünyaya gelen çocuklarının engelli olduğunu öğrenmeleri aile için hayal kırıklı̆̆ 1 ve derin bir üzüntü yaşamalarına neden olabilir (Nazlı, 2001).

Engelli kavramı genel olarak bedensel özellikleri ve öğrenme yeterlilikleri normale göre farklılık gösteren bireyler için kullanılmaktadır (Yavuz, 2016). Engellilik, değiştirilemeyen ve devamlılık arz eden bir durumdur ve engel türlerinden biri zihinsel yetersizliktir (Çoban Esen, 2003). Dünya Sağlık Örgütü (DSÖ) Uluslararası Hastalıklar ve Sağlık Durumlarının Sınıflandırılmasinda; zihinsel yetersizlik gelişim dönemlerinde tespit edilen, zihnin yetersiz gelişimi ve bilişsel, sosyal, dil ile ilişkili yeteneklerdeki bozulmalarla kendini gösteren bir durum olarak açıklamıştır. AZYED' in (Amerikan Zihinsel ve 
Gelişimsel Yeti Eksiklikleri Derneği) 2010 yönergesinde ise zihinsel yetersizlik "Zihinsel yeti eksikliği" terimi kullanılarak tanımlanmıştır. Bu tanıma göre "Zihinsel yeti eksikliği, 18 yaşından önce başlayan, zihinsel işlevlerde ve kavramsal, sosyal ve pratik uyumsal becerilerde kendini gösteren anlamlı sınırlıliklar olarak karakterize edilen bir yetersizliktir (AAIDD, 2010)". Kısaca zihinsel yetersizlik çocuğun yaşına oranla algılama, yönelim, bellek, soyutlama, neden-sonuç ilişkisi kurabilme, gerçeği kavrayabilme, yargılama, kendini ifade edebilme, öğrenme gibi yetilerinde yaşıtlarına göre geri olması durumu olarak kabul edilen bir engellilik türüdür (Eripek, 1996).

Zihinsel yetersizlikte dahil tüm engel durumları sadece engeli olan bireyi değil aynı zamanda onunla birlikte yaşayan ve aynı ortak payda da buluşan ailesini de ilgilendirmektedir (Yavuz, 2016). Aile engeli olmayan çocukların bile ilerde yaşayacakları hayatın şekillenmesi noktasında ciddi bir öneme sahipken engelli çocukların hayatlarında çok daha önemli bir unsurdur (Karaçengel, 2007). Zihinsel yetersizliği olan çocuğa sahip ebeveynler için, çocuğun bakım sorumluluklarına, eğitimine ve yaşamını nasıl idame ettirebileceğine yönelik düşünceler ciddi bir vicdan muhasebesine dönüşebilmektedir. Çocuğun yaşamı boyunca devam edecek bu süreçte aileler çok fazla sorunla karşlaşabilmektedir. Bu yorucu süreç pek çok kriz durumunu da beraberinde getirebilmektedir. Engeli olan çocuğun özel bakım ihtiyaçları, çocuğun var olan engeline ilişkin toplumun tutum ve yargıları, çocuğun içinde bulunduğu anın ve gelecekteki durumunun belirgin olmaması ve bunlara ek olarak ekonomik yetersizlikler ebeveynler için süreğen bir stres kaynağı olmaktadır. Dolayısıyla ebeveynlerin devam eden kriz ve stres durumlarına karşı uyum sağlamalarını gerektirmektedir. (Kaldırım, 2010).

Öte yandan aileler engelli çocuğa sahip olmayla ilgili yeterli deneyime ve çocuklarıyla nasıl ilgilenileceği ve onlara nasıl davranılacağı hakkında yeterli bilgiye sahip olmayabilirler. Bu durumda aileler yoğun bir kaygıyla ellerinden geleni yapmaya çalışarak bu durumun geçici olacağına inanmak isterler. Ayrıca ailede engelli bir çocuğun varlığı tutum ve değerlerin değişmesine de neden olur. Böyle koşullarda bazı ebeveynlerin yaşadıkları durumlarla mücadele ederken hissettikleri acı ve çaresizlik yaşamdan aldıkları doyumu olumsuz yönde etkileyebilir. Nitekim alan yazında, zihinsel yetersizliği olan çocuğa sahip ebeveynlerin yaşamdan aldıkları doyumun bu durumdan olumsuz etkileyebileceği görülmüş̧ür (Arman, 2009). 
Yaşam doyumu, bireyin, geçmiş yaşamı, içinde bulunduğu mevcut yaşamı ve gelecek yaşamı ile ilgili olan fikirlerini ifade eden bir kavramdır. (Diener ve Lucas, 1999). Diener'a (1984) göre, yaşam doyumu yalnızca depresyon ve kaygı gibi psikolojik rahatsızlıkların ortadan kaldırılmasıyla değil aynı zamanda olumlu ve sağlıklı kişilik özellikleriyle de ilişkilendirilir. Yaşam doyumu ile ilgili alan yazında, bu kavramın cinsiyet, yaş, eğitim düzeyi, kişinin sahip olduğu duygusal ve sosyal beceriler gibi çeşitli değişkenler ile ilişkili olduğu görülmektedir. Yaşam doyumu ile ilişkili olan değişkenlerden biri de bireylerin sahip olduğu problem çözme becerisi olabilir.

Bireyler yaşamları boyunca sosyal ve iş çevresiyle ilgili zorluklarla karşılaşır. Problemlerin çözülebilmesi, yaşamda karşılaşılan bu zorlukların üstesinden gelinebilmesiyle olur. Problem çözme becerisi, bireylerin çevresiyle baş etmesinde en önemli özelliklerinden olan sosyal uyumunu ve günlük yaşamdaki başarısını olumlu yönde etkilemektedir. Problem çözme becerileri yaşamın ilk döneminden itibaren kazandırılması gerekir ve yaşam boyu gerekli olur. Bu becerilerin kazandırılması bireylerin hem öğrenme süreçlerinde başarılı olmalarında hem de toplumsal ve kültürel hedeflere ulaşmalarında önemli bir rol oynamaktadır (Demirkıran, 2017). Bu doğrultuda bireylerin problem çözme becerileri ile yaşam doyumlarının ilişkili olabileceği ve problem çözme becerisindeki artışın bireylerin yaşam doyumları üzerinde olumlu etkiler doğurabileceği söylenebilir.

Yaşam doyumu ve problem çözme becerileri ile cinsiyet faktörünün ilişkili olabileceği düşünülmektedir. Öyle ki toplumda annelerin çocuk bak1mında daha fazla sorumluluk üstlendikleri ve problemli çocuklara karşı daha duyarlı davrandıkları görülmektedir. Özellikle yetersizliği olan çocuğa sahip anneler iş hayatına atılma ya da çalışıyorlarsa işlerinde yükselme gibi fırsatlarla daha az karşılaşmakta dolayısıyla anneler daha çok fedakârlıkta bulunmak zorunda kalabilmektedir (Demirkıran, 2017).

Yaşam doyumu ve problem çözme becerisi üzerinde ilişkili olduğu düşünülen bir diğer değişken ise kişinin deneyimlerinin bir göstergesi olan yaş faktörüdür. Alan yazında yetişkinlerin problem çözme becerileri, duruma veya konuya ilişkin bilgi ve tecrübelerinin bir yansıması olarak sunulmaktadır (Soden ve Pithers, 2001). Ayrıca ebeveynlerin eğitim durumları da problem çözme ve yaşam doyumunu etkileyebilir. Nitekim eğitimli bireylerin 
uyum yeteneğinin yüksek olduğu ve daha esnek davranışlar gösterebildikleri bu nedenle problemlerinin üstesinden daha kolay gelip etkili çözümler üretebildikleri ileri sürülmektedir (Stein ve Book, 2003).

Yaşam doyumu ve problem çözme becerisi ile ele alınması gereken bir diğer değişkenin çocuğun tanı durumu olduğu düşünülmektedir. Çünkü çocuğun zihinsel yetersizlik düzeyi arttıkça ebeveynlerin, duygusal tükenmişlikleri de artmaktadır (Arman, 2009). Benzer şekilde çocuğun engel sayısındaki artış, ailenin karşılaştığı problemlerin artmasına ve ebeveynlerin bu problemlerin üstesinden gelmelerinin zorlaşmasına neden olabilmektedir (Acar, 2009). Çocuğun aldığı özel eğitim süresi de üzerinde durulması gereken bir başka değişkendir. Çocuğun engel durumuna yönelik özel eğitim desteği alması ve ailenin de eğitim sürecine katılması ebeveynlerin hem problemlerle baş etme becerilerinin gelişmesine hem de bu süreçteki olumsuz durumlardan daha az etkilenmelerine katkı sağlayabilmektedir (Özgür ve Zan, 2004).

Alan yazında zihinsel yetersizliği olan çocuğa sahip ebeveynlere ilişkin yurt dışı çalışmalarının oldukça yaygın olduğu bilinmektedir. Ülkemizde ise özellikle son yıllarda zihinsel yetersizliği olan çocuğa sahip ebeveynlere yönelik yapılan çalışmalarda önemli bir artış tespit edilse de bu çalışmaların sınırlı olduğu görülmektedir. Oysaki Türkiye' de tahminen 9 milyon engelli birey yaşamaktadır (Ey-Der, 2019). Başbakanlık Devlet İstatistik Enstitüsü ve Başbakanlık Özürlüler İdaresi Başkanlığı tarafından yapılan 2002 Türkiye Özürlüler Araştırması' nın 2018' de güncellenen sonuçlarına göre; Türkiye'de engelli bireyler toplam nüfusun \% 12.3' ü oluşturmakta ve bu grubun içinde zihinsel yetersizliği olan bireylerin ise toplam nüfusa oranının \% 0.4 olduğu bilinmektedir. Toplum nüfusu üzerinde yadsınamaz bir gerçek olan bu oran zihinsel yetersizliği olan bireyler ve yakın çevreleri üzerinde yapılması gereken araştırmaları daha da elzem hale getirmektedir. Bununla birlikte bu araştırmada ele alınan zihinsel yetersizliği olan çocuğa sahip ebeveynlerin problem çözme becerileri ve yaşam doyumlarının bir arada incelendiği yurt içinde herhangi bir çalışmaya rastlanmamıştır.

Zihinsel yetersizliği olan çocuğa sahip ebeveynlerin yaşam boyunca karşılaştıkları güçlüklerin onların psikolojik sağlıkları üzerindeki etkisi dikkate alındığında, yaşam doyumu ve problem çözme becerileri ile ilişkili olabilecek olan sosyal ve eğitsel değişkenlerin belirlenmesi bu araştırmanın problemini 
oluşturmaktadır. Zihinsel yetersizliği olan çocuğa sahip ebeveynlerin problem çözme becerileri ve yaşam doyumlarının diğer değişkenlerle beraber tespiti, yaşanan olumsuzlukların saptanması ve bunların çözümüne yönelik öneriler ve hizmetler geliştirebilmek adına araştırmaya değer görülmüştür. Dolayısıyla yapılan bu çalışmanın ilgili literatüre katkı sunacağı düşünülmektedir.

Söz konusu bu kapsamda yapılan bu araştırmanın temel amacı zihinsel yetersizliği olan çocuğa sahip ebeveynlerin problem çözme becerileri ve yaşam doyumları arasındaki ilişkinin saptanmasıdır. Ayrıca bu kavramlar cinsiyet, yaş, eğitim düzeyi, çocuğun tanı durumu, özel eğitim alma süresi ve birden fazla engelinin olup olmaması değişkenleri açısından da incelenmiştir.

Bu bağlamda aşağıdaki problem durumları için cevaplar aranmıştır:

1. Ebeveynlerin yaşam doyumları ile problem çözme becerileri arasında anlamlı bir ilişki var mıdır?

2. Ebeveynlerin problem çözme becerileri ve yaşam doyumları cinsiyetlerine göre anlamlı bir farklılık göstermekte midir?

3. Ebeveynlerin problem çözme becerileri ve yaşam doyumları yaşlarına göre anlamlı bir farklılık göstermekte midir?

4. Ebeveynlerin problem çözme becerileri ve yaşam doyumları çocuklarınin tanı durumuna göre anlamlı bir farklılık göstermekte midir?

5. Ebeveynlerin problem çözme becerileri ve yaşam doyumları çocuklarının aldığı özel eğitim süresine göre anlamlı bir farklılık göstermekte midir?

6. Ebeveynlerin problem çözme becerileri ve yaşam doyumları çocuklarının birden fazla engelinin olup olmaması durumuna göre anlamlı bir farklılık göstermekte midir?

7. Ebeveynlerin problem çözme becerileri ve yaşam doyumları eğitim düzeylerine göre anlamlı bir farklılık göstermekte midir?

8. Ebeveynlerin yaşam doyumlarını anlamlı yordayan değişkenler nelerdir?

\section{Yöntem}

Bu araştırmada ilişkisel tarama yöntemi kullanılmıştır. İlişkisel tarama yöntemi, "iki ya da daha çok sayıdaki değişken arasında birlikte değişim varlığını 
ve/ya da derecesini belirlemeyi amaçlayan araştırma modelidir" (Karasar, 2009).

\section{Çalışma Grubu}

Araştırmanın çalışma grubu Erzincan İli'nde bulunan Özel Eğitim Mesleki Eğitim ve Özel Eğitim İş Uygulama Okulları'nda eğitimine devam eden zihinsel yetersizliği olan 138 çocuğun ebeveyninden oluşmaktadır. Katılımcıların 94' ü kadın 44'ü erkektir. Ebeveynler arasında en çok görülen yaş grubu 35-44 yaş iken (\%42.8); en az görülen yaş grubu ise 55 yaş ve üstü katılımc1lardır (\%8.7). Katılımclar arasında ilkokul mezunu olanların \%44.9 ile en yüksek oranda olduğu; buna karşın $\% 5,8^{\prime} \operatorname{sinin}$ ise okuryazar düzeyde olmadığ1 tespit edilmiştir. Ebeveynlerin çocuklarının \%50.7 'sinin tanı durumlarının orta düzeyde \%24.6' sının ise hafif düzeyde olduğu görülmüştür. Ayrıca ebeveynlerin çocuklarının aldığı özel eğitim süresine bakıldığında \%46.4' ünün 7 yıl ve üstü süredir bu eğitime devam etmekte olduğu, \%13.8'inin ise çocuğunun ikinci bir engeli bulunduğu tespit edilmiştir.

\section{Veri Toplama Araçlan}

Araştırmada veri toplamak amacıyla zihinsel yetersizliği olan çocuğa sahip ebeveynlere araştırmacı tarafından geliştirilen 'Kişisel Bilgi Formu', Diener ve ark (1985) tarafından geliştirilen ve Türkçeye uyarlama çalışması Dağlı ve Baysal (2016) tarafından yapılan "Yaşam Doyumu Ölçeği", Yaman ve Dede (2008) tarafından geliştirilen 'Yetişkinler İçin Problem Çözme Ölçeği" uygulanmıştır.

Yaşam Doyumu Ölçeği: Yaşam Doyumu Ölçeği kişinin öznel iyilik durumunu ölçmektedir. Tek alt boyut ve 5 maddeden oluşan 5 ' li likert tipinde bir ölçektir. Ölçekten alınabilecek puanlar 5 ile 25 arasında değişmektedir. Ölçekten alınan yüksek puan kişinin yaşam doyumunun yüksek olduğunu gösterir (Dağlı ve Baysal, 2016). Yaşam Doyumu Ölçeği, Diener ve ark. (1985) tarafından geliştirilmiştir. Ölçeğin Türkçeye uyarlamasını Dağlı ve Baysal (2016) gerçekleştirmiştir. Açıklanan toplam varyans açımlayıcı faktör analizi sonucunda \%68,389 olarak belirlenmiştir. Ölçek maddelerinin faktör yükleri 0.728 ile 0,893 arasında hesaplanmıştır. Ölçeğin test-tekrar test güvenirliği hesaplanırken, korelasyon katsayısı $r=0,97(\mathrm{p}<, 01)$ olarak saptanmıştır. Ölçeği 
oluşturan maddelerin iç tutarlığını veren Cronbach Alpha Katsayısı 0,88 olarak hesaplanmıştır. Bu çalışmada da ölçeğin Cronbach Alpha Katsayısı 0,91 olarak hesaplanmıştır.

Yetişkinler İçin Problem Çözme Becerileri Ölçeği: Yetişkinlerin günlük yaşamlarındaki çeşitli problemlere yönelik problem çözme becerilerini ölçmek amacıyla, $5^{\prime}$ li likert tipinde 5 alt boyut ve 18 maddeden oluşan bu ölçek Yaman ve Dede (2008) tarafından geliştirilmiştir. Ölçeğe verilebilecek cevaplar sonucunda alınabilecek en düşük puan 18, en yüksek puan 90'dır. Ölçekten alınan puan arttıkça cevaplayan bireylerin problem çözme beceri düzeylerinin de arttığı belirtilmektedir. Ölçeğe ilişkin güvenilirlik belirleme çalışmaları sonucunda, tüm ölçeğin Cronbach Alfa iç tutarlılık katsayısının .88 olduğu tespit edilmiştir (Yaman ve Dede, 2008). Bu çalışmada ölçeğin test-tekrar test güvenirliği hesaplanırken korelasyon katsayısı r=0,97 ( $\mathrm{p}<, 01)$ olarak saptanmıştır.

Kişisel Bilgi Formu: Bu form zihinsel yetersizliği olan çocuğa sahip ebeveynlerin; cinsiyetini, yaşını, eğitim düzeyini; çocuğunun tanısını, başka bir engelinin olup olmama durumunu ve aldığı özel eğitimin süresini belirlemek amacıyla araştırmacı tarafından hazırlanan 7 kapalı uçlu sorudan oluşmaktadir.

\section{Verilerin Analizi}

İlk olarak veri setindeki tek değişkenli uç değerler incelenmiştir. Tek değişkenli uç değerler $Z$ puanlarının hesaplanması yoluyla belirlenmiştir. $Z$ puanı [-3,3] aralığı dışında kalan değerler uç değer olarak değerlendirilmiş̧tir. Z puanları hesaplandıktan sonra bütün $Z$ puanlarının $[-3,3]$ aralığında kaldığı görülmüş ve veri setinde tek değişkenli uç değerlerden kaynaklı herhangi bir değişiklik yapılmamıştır.

Tek değişkenli normallik varsayımı betimsel istatistiklerden çarpıklık ve basıklık katsayıları yoluyla incelenmiştir. Çarpıklık ve basıklık değerlerinin [1,1] aralığında olması tek değişkenli normallik varsayımının sağlandığını gösterir (Büyüköztürk, 2012). Ölçekler için çarpıklık ve basıklık katsayıları hesaplanmıştır. Yapılan incelemede çarpıklık katsayısı değerleri $[-1,1]$ aralığında olduğu görülmüştür. Basıklık katsayıları incelendiğinde problem çöz- 
meye ait basıklık katsayısı değerlerinin [-1,1] aralığında olduğu; yaşam doyumuna ait basıklık katsayısının ise -1,236 olduğu görülmüştür. Elde edilen çarpıklık ve basıklık katsayıları birlikte değerlendirildiğinde boyutların çoğunluğunun çarpıklık ve basıklık katsayıları için istenen aralıkta yer aldığı görülmektedir. Bu sebeple tek değişkenli normallik varsayımının sağlandığı kabul edilmiştir.

Elde edilen veriler SPSS (Statistical Package for Social Sciences) for Windows 20.0 programı kullanılarak analiz edilmiştir. Verilerin analizinde zihinsel yetersizliği olan çocuğa sahip ebeveynlerin cinsiyetlerine ve çocukların aldığı özel eğitim süresine göre problem çözme becerileri ile yaşam doyumlarının karşılaştırılmasında parametrik testlerden Bağımsız Örneklem t Testi ve Tek Yönlü Varyans Analizi kullanılmıştır. Buna karşın zihinsel yetersizliği olan çocuğa sahip ebeveynlerin problem çözme becerileri ile yaşam doyumlarının; yaş, eğitim durumu, çocuklarının tanı durumu ve çocuğun birden fazla engelinin olup olmaması değişkenlerine göre farklılaşıp farklılaşmadığ parametrik olmayan testlerden Kruskal Wallis H ve Maan Whitney U Testi ile analiz edilmiştir. Zihinsel yetersizliği olan çocuğa sahip ebeveynlerin yaşam doyumu ve problem çözme becerileri arasındaki ilişkinin incelenmesinde de Pearson Korelasyon analizine başvurulmuştur. Ayrica zihinsel yetersizliği olan çocuğa sahip ebeveynlerin yaşam doyumlarını yordayan değişkenlerin belirlenmesinde çoklu Regresyon analizine başvurulmuştur.

\section{Bulgular}

Bu bölümde ilk olarak zihinsel yetersizliği olan çocuğa sahip ebeveynlerin problem çözme becerileri ve yaşam doyumlarının cinsiyet, yaş, eğitim durumu, çocuğun tanı durumu, çocuğun engel durumu, çocuğun aldığı özel eğitim süresi gibi değişkenler açısından farklılaşıp farklılaşmadığı; zihinsel yetersizliği olan çocuğa sahip ebeveynlerin problem çözme becerilerinin yaşam doyumlarının yordayıcısı olup olmadığı incelenmiş ve elde edilen bulgulara yer verilmiştir.

Zihinsel yetersizliği olan çocuğa sahip ebeveynlerin yaşam doyumları ile problem çözme becerileri arasında anlamlı bir ilişki olup olmadığı Pearson Momentler Çarpım Korelasyonu ile incelenmiş, elde edilen bulgular Tablo 1' de sunulmuştur. 
Tablo 1. Zihinsel Yetersizliği Olan Çocuğa Sahip Ebeveynlerin Yaşam Doyumu ile Problem Çözme Becerileri Arasındaki İlişkiyi Gösteren Pearson Momentler Çarpım Korelasyonu

\begin{tabular}{lll}
\hline Değişken & YD & PÇ \\
\hline Yaşam Doyumu (YD) & - & $.592^{*}$ \\
\hline Problem Çözme (PÇ) & $.592^{*}$ & - \\
\hline
\end{tabular}

Tablo 1 incelendiğinde zihinsel yetersizliği olan çocuğa sahip ebeveynlerin yaşam doyumu ile problem çözme becerileri arasında ( $\mathrm{r}=.592, p<.05)$, pozitif yönde manidar bir ilişki olduğu elde edilen bulgular arasındadır.

Zihinsel yetersizliği olan çocuğa sahip ebeveynlerin problem çözme becerileri ve yaşam doyumlarının cinsiyetlerine göre anlamlı bir farklılık gösterip göstermediği Bağımsız Örneklem T Testi ile incelenmiş, elde edilen bulgular Tablo 2' te sunulmuştur.

Tablo 2. Zihinsel Yetersizliği Olan Çocuğa Sahip Ebeveynlerin Yaşam Doyumu ve Problem Çözme Becerisinin Cinsiyetleri Açısından Farklılaşmasına İlişkin Bağımsız Örneklem T Testi Sonuçlan

\begin{tabular}{lllllllll}
\hline & Cinsiyet & $\mathbf{N}$ & $\overline{\boldsymbol{X}}$ & $\mathbf{S}$ & $\mathbf{s d}$ & $\mathbf{t}$ & $\mathbf{p}$ & $\eta^{2}$ \\
\hline Yaşam & Kadın & 94 & 13.11 & 4.87 & \multirow{2}{*}{136} & \multirow{2}{*}{-3.251} & \multirow{2}{*}{.001} & \multirow{2}{*}{.007} \\
Doyumu & Erkek & 44 & 16.15 & 5.61 & & \multirow{2}{*}{0} \\
\hline $\begin{array}{l}\text { Problem } \\
\text { Çözme }\end{array}$ & Kadın & 94 & 62.03 & 19.66 & \multirow{2}{*}{136} & \multirow{2}{*}{-1.750} & \multirow{2}{*}{.082} & \multirow{2}{*}{.022} \\
\hline
\end{tabular}

Tablo 2' ye göre erkekler ve kadınların yaşam doyumu $\left(t_{(136)}=-3.251\right.$, $\mathrm{p}<.01)$, puanları arasında manidar bir farklılık bulgulanmıştır $(p<.05)$. Erkeklerin yaşam doyumlarının ( $\bar{X}=16.15)$ kadınlara göre $(\bar{X}=13.11)$ daha yüksek olduğu tespit edilmiştir. Bu bulgu yaşam doyumu ile cinsiyet arasında anlamlı bir ilişkinin olduğu şeklinde de yorumlanabilir. Yapılan test sonucunda hesaplanan $\eta^{2}$ değeri .007'dir. Buna göre yaşam doyumu puanlarında gözlenen varyansın yaklaşık \%.7'sinin cinsiyete bağlı olduğu ifade edilebilir. Buna karşın erkekler ve kadınların problem çözme becerileri $\left(t_{(136)}=-1.750\right)$ arasında manidar bir farklılık bulgulanmamıştr. ( $p>.05)$.

Zihinsel yetersizliği olan çocuğa sahip ebeveynlerin problem çözme becerileri ve yaşam doyumlarının yaşlarına göre anlamlı bir farklılık gösterip göstermediği Kruskal Wallis Analizi ile incelenmiş, elde edilen bulgular Tablo 3’ de sunulmuştur. 
Tablo 3. Zihinsel Yetersizliği Olan Çocuğa Sahip Ebeveynlerin Yaşam Doyumu ve Problem Çözme Becerisinin Yaşlarn Açısından Farkhlaşmasına İlişkin Kruskal Wallis Analizi Sonuçları

\begin{tabular}{|c|c|c|c|c|c|c|c|}
\hline & Yaş & $\mathbf{N}$ & $\bar{X}$ & SO & $\chi^{2}$ & sd & p \\
\hline \multirow{4}{*}{ Yaşam Doyumu } & $25-34$ & 21 & 13,5238 & 65,45 & \multirow{4}{*}{,399 } & \multirow{4}{*}{3} & \multirow{4}{*}{,940 } \\
\hline & $35-44$ & 59 & 14,2373 & 70,96 & & & \\
\hline & $45-54$ & 46 & 14,1957 & 70,35 & & & \\
\hline & 55 ve üzeri & 12 & 13,9167 & 66,17 & & & \\
\hline \multirow{4}{*}{ Problem Çözme } & $25-34$ & 21 & 60,9048 & 62,67 & \multirow{4}{*}{2,815} & \multirow{4}{*}{3} & \multirow{4}{*}{421} \\
\hline & $35-44$ & 59 & 66,5593 & 75,65 & & & \\
\hline & $45-54$ & 46 & 63,1739 & 67,14 & & & \\
\hline & 55 ve üzeri & 12 & 60,1667 & 60,25 & & & \\
\hline
\end{tabular}

Tablo 3' e bakıldığında yaşam doyumu $\left(\chi^{2}=399\right)$ ve problem çözme becerisinin ( $\left.\chi^{2}=2,815\right)$ ebeveynlerin yaşlarına göre manidar farklılık gösterip göstermediğini belirlemek için yapılan analiz sonucunda yaşam doyumu ve problem çözme becerisinin ebeveynlerin yaşlarına göre manidar bir farklılık göstermediği tespit edilmiştir ( $p>.05)$

Zihinsel yetersizliği olan çocuğa sahip ebeveynlerin problem çözme becerileri ve yaşam doyumlarının çocuklarının tanı durumuna göre anlamlı bir farklılık gösterip göstermediği Kruskal Wallis Analizi ile incelenmiş, elde edilen bulgular Tablo 4’ te sunulmuştur.

Tablo 4. Zihinsel Yetersizliği Olan Çocuğa Sahip Ebeveynlerin Yaşam Doyumu ve Problem Çözme Becerisinin Çocuğunun Tanı Durumu (Hafif, Orta, Ağır, Çok Ağır)Açısından Farklılaşmasına İlişkin Kruskal Wallis Analizi Sonuçları

\begin{tabular}{|c|c|c|c|c|c|c|c|c|}
\hline & Tanı & $\mathbf{N}$ & $\bar{X}$ & SO & $\chi^{2}$ & sd & $\mathbf{P}$ & $\begin{array}{l}\text { Anlamlı } \\
\text { Fark }\end{array}$ \\
\hline \multirow{4}{*}{ Yaşam Doyumu } & Hafif (H) & 34 & 16,1176 & 84,22 & \multirow{4}{*}{13,530} & \multirow{4}{*}{3} & \multirow{4}{*}{,004 } & \\
\hline & Orta $(\mathrm{O})$ & 70 & 14,3857 & 72,07 & & & & H- A \\
\hline & Ağır (A) & 27 & 11,5926 & 50,30 & & & & H-ÇA \\
\hline & Çok Ağır (ÇA) & 7 & 10,8571 & 46,36 & & & & $\mathrm{O}-\mathrm{A}$ \\
\hline \multirow{4}{*}{ Problem Çözme } & Hafif $(\mathrm{H})$ & 34 & 67,0000 & 75,60 & \multirow{4}{*}{16,131} & \multirow{4}{*}{3} & \multirow{4}{*}{,001 } & H-ÇA \\
\hline & Orta $(\mathrm{O})$ & 70 & 66,9429 & 75,69 & & & & O- ÇA \\
\hline & Ağır (A) & 27 & 60,1481 & 59,26 & & & & A-ÇA \\
\hline & Çok Ağır (ÇA) & 7 & 35,1429 & 17,43 & & & & \\
\hline
\end{tabular}

Tablo 4 incelendiğinde zihinsel yetersizliği olan çocuğa sahip ebeveynlerin yaşam doyumlarında çocuklarının tanı durumuna göre manidar bir farklılık saptanmıştır $\left(\chi^{2}(\mathrm{sd}=3, \mathrm{n}=138)=13,530, p<.05\right)$. Bu farklılı̆̆ın hangi grup- 
lar arasında olduğunu tespit etmek için Mann Whitney U testi ile kıyaslamalar yapılmıştır. Yapılan kıyaslamalar sonucunda farklılığın hafif düzey zihinsel yetersizliği olan çocuğa sahip ailelerle ağır düzey zihinsel yetersizliği olan çocuğa sahip aileler arasında ( $\mathrm{U}=274,00 ; \mathrm{z}=-2,698)$ hafif düzeyde zihinsel yetersizliği olan çocuğa sahip aileler lehine manidar farklılık, hafif düzey zihinsel yetersizliği olan çocuğa sahip ailelerle çok ağır düzey zihinsel yetersizliği olan çocuğa sahip aileler arasında ( $U=62,000 ; z=-1,985)$ hafif düzeyde zihinsel yetersizliği olan çocuğa sahip aileler lehine manidar farklılık ve orta düzey zihinsel yetersizliği olan çocuğa sahip ailelerle ağır düzey zihinsel yetersizliği olan çocuğa sahip aileler arasında ( $U=617,500 ; z=-2,643)$ orta düzeyde zihinsel yetersizliği olan çocuğa sahip aileler lehine manidar farkllık bulgulanmıştır. Sıra ortalamaları dikkate alındığında, hafif, orta ve ağır düzeyde zihinsel yetersizliği olan çocuğa sahip ailelerin yaşam doyum düzeylerinin çok ağır düzeyde zihinsel yetersizliği olan çocuğa sahip ailelere göre daha yüksek olduğu anlaşılmaktadır. Ayrıca Tablo 4' de zihinsel yetersizliği olan çocuğa sahip ebeveynlerin problem çözme becerilerinde çocuklarının tanı durumuna göre manidar bir farklılık olduğu görülmektedir $\left(\chi^{2}(\mathrm{sd}=3, \mathrm{n}=138)=16,131\right.$, $p<.05$ ). Bu farklılığın hangi gruplar arasında olduğunu tespit etmek için Mann Whitney U testi ile kıyaslamalar yapılmıştır. Yapılan kıyaslamalar sonucunda farklılığın hafif düzey zihinsel yetersizliği olan çocuğa sahip ailelerle çok ağır düzey zihinsel yetersizliği olan çocuğa sahip aileler arasında (U=18,000; $z=-$ 3,502 ) hafif düzeyde zihinsel yetersizliği olan çocuğa sahip aileler lehine manidar farklılık, orta düzey zihinsel yetersizliği olan çocuğa sahip ailelerle çok ağır düzey zihinsel yetersizliği olan çocuğa sahip aileler arasında $(U=45,000$; $z=3,547)$ orta düzeyde zihinsel yetersizliği olan çocuğa sahip aileler lehine manidar farklılık ve ağır düzey zihinsel yetersizliği olan çocuğa sahip ailelerle çok ağır düzey zihinsel yetersizliği olan çocuğa sahip aileler arasında $(\mathrm{U}=31,000 ; z=-2,709)$ ağır düzeyde zihinsel yetersizliği olan çocuğa sahip aileler lehine manidar farklılık bulgulanmıştır. Sıra ortalamaları dikkate alınd1ğında, hafif, orta ve ağır düzeyde zihinsel yetersizliği olan çocuğa sahip ailelerin problem çözme becerilerinin çok ağır düzeyde zihinsel yetersizliği olan çocuğa sahip ailelere göre daha yüksek olduğu anlaşılmaktadır.

Zihinsel yetersizliği olan çocuğa sahip ebeveynlerin problem çözme becerileri ve yaşam doyumlarının çocuklarının birden fazla engelinin olup olmaması durumuna göre anlamlı bir farklılık gösterip göstermediği Mann Whitney U Testi incelenmiş, elde edilen bulgular Tablo 5’ de sunulmuştur. 
Tablo 5. Zihinsel Yetersizliği Olan Çocuğa Sahip Ebeveynlerin Yaşam Doyumu ve Problem Çözme Becerisinin Çocuklarının Engel Durumu Sayısı Açısından Farklılaşmasına İlişkin Mann Whitney U Testi Sonuçlarn

\begin{tabular}{llllllll}
\hline & $\begin{array}{l}\text { Engel } \\
\text { Durumu }\end{array}$ & $\mathbf{N}$ & $\overline{\boldsymbol{X}}$ & SO & ST & $\mathbf{U}$ & $\mathbf{p}$ \\
\hline Yaşam Doyumu & Evet & 19 & 14,2105 & 69,50 & 1320,50 & \multirow{2}{*}{1130,500} & \multirow{2}{*}{1,000} \\
& Hayır & 119 & 14,0672 & 69,50 & 8270,50 & \\
& Evet & 19 & 63,4211 & 64,61 & 1227,50 & \multirow{2}{*}{1037,500} & \multirow{2}{*}{, 565} \\
\hline Problem Çözme & Hayır & 119 & 64,1092 & 70,28 & 8363,50 & & \\
& & & & &
\end{tabular}

Tablo 5' e göre birden fazla engeli olan çocuğa sahip olan ve olmayan ebeveynlerin yaşam doyumu ve problem çözme becerileri arasında manidar bir farklılık bulunmamıştır ( $\mathrm{p}>$.05).

Zihinsel yetersizliği olan çocuğa sahip ebeveynlerin problem çözme becerileri ve yaşam doyumlarının çocuklarının aldığı özel eğitim süresine göre anlamlı bir farklılık gösterip göstermediği Tek Yönlü Varyans Analizi ile incelenmiş, elde edilen bulgular Tablo 6 ' da sunulmuştur.

Tablo 6. Zihinsel Yetersizliği Olan Çocuğa Sahip Ebeveynlerin Yaşam Doyumu ve Problem Çözme Becerisinin Çocuklarının Aldiğı Özel Eğitim Süresi Açısından Tek yönlü Varyans Analizi Sonuçlar

\begin{tabular}{|c|c|c|c|c|c|c|c|}
\hline Faktörler & & $\begin{array}{l}\text { Kareler } \\
\text { Toplamı }\end{array}$ & Sd & $\begin{array}{l}\text { Kareler } \\
\text { Ortalamas1 }\end{array}$ & $\mathbf{F}$ & $\eta^{2}$ & $\begin{array}{l}\text { Anlamlı } \\
\text { Fark }\end{array}$ \\
\hline \multirow[t]{3}{*}{ Yaşam Doyumu } & Gruplar Arası & 194,034 & 2 & 97,017 & 4,459 & ,015.05 & A-C \\
\hline & Grup içi & 3652,923 & 135 & 27,059 & & & B-C \\
\hline & Toplam & 3846,957 & 137 & & & & \\
\hline \multirow[t]{3}{*}{ Problem Çözme } & Gruplar Arası & 400,075 & 2 & 200,038 &, 517 &, 598 & \\
\hline & Grup içi & 52241,896 & 135 & 386,977 & & & \\
\hline & Toplam & 52641,971 & 137 & & & & \\
\hline
\end{tabular}

( $A=3$ yıl altı; $B=3$ ile 7 yıl arası; $C=7$ yıl üstü)

Tablo 6 incelendiğinde yaşam doyumu puanları $(\mathrm{LF}=3.278 ; \mathrm{p}<.05)$ ve problem çözme puanları için $(\mathrm{LF}=3,199 ; \mathrm{p}<.05)$ varyansların homojenliğinin sağlanamadığı görülmüş, bu nedenle Welch'in ANOVA testi kullanılmıştır (Moder, 2010). Analiz sonuçları incelendiğinde yaşam doyumunun ebeveynlerin çocuklarının özel eğitim süresine göre istatistiksel olarak anlamlı

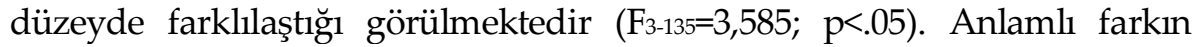
kaynağını tespit etmek üzere LSD testi yapılmıştır. LSD testi sonuçları A-B grupları arasında B lehine ve A-C grupları arasında C lehine bulgulanmıştır. 
Etki büyüklüğünü belirlemek için hesaplanan eta kare değerinin düşük düzeyde olduğu saptanmış ( $\eta 2=.05)$, bu durumda özel eğitim süresinin gözlenen varyansın \% 5'inin yaşam doyumuna bağlı olduğu söylenebilir. Buna karşın zihinsel yetersizliği olan çocuğa sahip ebeveynlerin çocuklarının özel eğitim süresi açısından problem çözme becerileri arasında manidar bir farklılık bulgulanmamıştır. ( $\mathrm{p}>$.05).

Zihinsel yetersizliği olan çocuğa sahip ebeveynlerin problem çözme becerileri ve yaşam doyumlarının eğitim düzeylerine göre anlamlı bir farklılık gösterip göstermediği Kruskal Wallis Analizi ile incelenmiş, elde edilen bulgular Tablo 7' de sunulmuştur.

Tablo 7. Zihinsel Yetersizliği Olan Çocuğa Sahip Ebeveynlerin Yaşam Doyumu ve Problem Çözme Becerisinin Eğitim Düzeyleri Açısından Farklılaşmasına İlişkin Kruskal Wallis Analizi Sonuçları

\begin{tabular}{|c|c|c|c|c|c|c|c|}
\hline & Tanı & $\mathbf{N}$ & $\bar{X}$ & SO & $\chi^{2}$ & sd & p \\
\hline \multirow{6}{*}{$\begin{array}{l}\text { Yaşam } \\
\text { Doyumu }\end{array}$} & Okur- Yazar Değil & 8 & 15,6250 & 82,69 & \multirow{6}{*}{7,220} & \multirow{6}{*}{5} & \multirow{6}{*}{ 205 } \\
\hline & Okur-Yazar & 10 & 14,5000 & 73,35 & & & \\
\hline & İkokul & 62 & 13,0484 & 60,94 & & & \\
\hline & Ortaokul & 20 & 13,6000 & 66,68 & & & \\
\hline & Lise & 28 & 15,6786 & 81,98 & & & \\
\hline & Üniversite & 10 & 15,4000 & 78,90 & & & \\
\hline \multirow{6}{*}{$\begin{array}{l}\text { Problem } \\
\text { Çözme }\end{array}$} & Okur-Yazar Değil & 8 & 64,3750 & 69,31 & \multirow{6}{*}{5,987} & \multirow{6}{*}{5} & \multirow{6}{*}{,307 } \\
\hline & Okur-Yazar & 10 & 59,0000 & 52,85 & & & \\
\hline & İlkokul & 62 & 64,4677 & 71,10 & & & \\
\hline & Ortaokul & 20 & 58,9000 & 56,60 & & & \\
\hline & Lise & 28 & 67,7500 & 80,25 & & & \\
\hline & Üniversite & 10 & 65,7000 & 72,10 & & & \\
\hline
\end{tabular}

Tablo 7' ye göre zihinsel yetersizliği olan çocuğa sahip ebeveynlerin yaşam doyumu ve problem çözme becerisinin ebeveynlerin eğitim düzeyi aç1sından manidar bir farklılık göstermediği bulgulanmamıştır ( $p>.05$ ).

Araştırma kapsamında yapılan analizler sonucunda yaşam doyumu ile ilişkili olduğu belirlenen problem çözme becerisi, cinsiyet, çocuğun aldığ özel eğitim süresi ve tanı durumu değişkenleri üzerinden regresyon analizi gerçekleştirilmiş, elde edilen sonuçlar Tablo 8' de verilmiştir. Regresyon analizini yürütebilmek için çocuğun aldığı özel eğitim süresi ve tanı durumu değişkenleri ilk önce "kukla (dummy)" değişken olarak kodlanmıştır. 
Tablo 8. Zihinsel Yetersizliği Olan Çocuğa Sahip Ebeveynlerin Yaşam Doyumlarnnn Yordanmasına İlişkin Çoklu Regresyon Analizi Sonuçlan

\begin{tabular}{|c|c|c|c|c|c|c|c|c|c|c|}
\hline Model & Değişken & B & S.H. & Beta & $\mathbf{t}$ & $\begin{array}{l}\text { İkili } \\
\text { r }\end{array}$ & Kısmi r & $\mathbf{R}$ & $\mathbf{R}^{2}$ & $\mathbf{F}$ \\
\hline \multirow{2}{*}{1} & Sabit & 3,847 & 1,251 & - & $3,076^{*}$ & - & ,592 & \multirow{2}{*}{, 592} & \multirow{2}{*}{,350 } & \multirow{2}{*}{73,281} \\
\hline & $\mathrm{PC}$ & ,160 & ,019 &, 592 & $8,560^{* *}$ & ,592 & - & & & \\
\hline \multirow{3}{*}{2} & Sabit & 4,120 & 1,187 & - & $3,472^{* *}$ & - & 626 & \multirow{3}{*}{ 649 } & \multirow{3}{*}{,421 } & \multirow{3}{*}{49,097} \\
\hline & PÇ & 166 & ,018 & 613 & $9,336^{* *}$ & ,592 & -330 & & & \\
\hline & Süre & $-3,722$ & ,915 &,- 267 & $-4,067^{* *}$ &,- 218 & - & & & \\
\hline \multirow{4}{*}{3} & Sabit & 3,845 & 1,156 & & $3,326^{* *}$ & - & 628 & \multirow{4}{*}{ 677 } & \multirow{4}{*}{, 458 } & \multirow{4}{*}{37,765} \\
\hline & PÇ & ,162 & ,017 & ,598 & $9,339 * *$ & ,592 &,- 358 & & & \\
\hline & Süre & $-3,955$ & 892 &,- 284 & $-4,433^{* *}$ & -218 & 253 & & & \\
\hline & Tanı & 2,377 & 785 & 194 & $3,027^{*}$ & ,220 & - & & & \\
\hline
\end{tabular}

Not: ${ }^{*}=p<.05 ;{ }^{* *}=p<.001 ;$ PÇ= problem çözme; Süre= Özel eğitim süresi; Tanı= Çocuğun tanı durumu

Bu kapsamda cinsiyet için kadın "0", erkek " 1 " olarak, gelir durumu değişkeni için 0- 1404 TL ve 1405- 2900 TL arası "0", 2900 TL üstü "1" olarak, çocuğun tanı durumu değişkeni için orta, ağır ve çok ağır düzey " 0 ”, hafif düzey " 1 " olarak, çocuğun özel eğitim süresi değişkeni için ise 3 yıl ve üstü " 0 ", 3 yil alt1 " 1 " olarak kodlanmıştur.

Zihinsel yetersizliği olan çocuğa sahip ebeveynlerin yaşam doyumlarını yordayan değişkenleri belirlemek için değişkenlerin istatistiksel değerlerine bağlı olarak yordama sırasının belirlendiği adımsal regresyon analizi yürütülmüş̧ür. Adımsal regresyon analizi model testinden ziyade model kurmada daha uygun görülmektedir (Tabachnick ve Fidell, 2013). Bu nedenle zihinsel yetersizliği olan çocuğa sahip ebeveynlerin yaşam doyumlarına ilişkin çalışmaların yeterli sayıda olmadığı düşünüldüğünde bu konuya ilişkin modeller geliştirebilecek çalışmalara yön vermesi amacıyla adımsal regresyon analizi tercih edilmiştir.

Tablo 8 incelendiğinde açılanan varyansların istatistiksel olarak anlamlı olduğu görülmüştür ( $\left.F_{1-136}=73.281 ; F_{2-135}=49.097 ; F_{3-134}=37.765, p<.000\right)$. Yordayan değişkenler model üzerinde yordama işlemini başarı ile yerine getirdiğinden bir sonraki aşamada yaşam doyumunun yordanmasına ilişkin adımsal çoklu regresyon analizi uygulanmıştır.

Adımsal regresyon analizinin birinci adımında Problem Çözme Becerisinin ebeveynlerin yaşam doyumlarını yordama da ki beta katsayısı ,592 olup, beta katsayısının anlamlılığına ilişkin $t$ testi sonuçları anlamlı bulunmuştur 


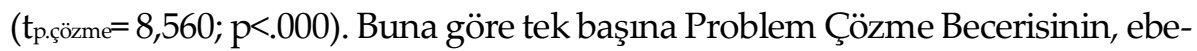
veynlerin yaşam doyumlarını yönelik tutumlarının \% 35'ini açıkladığı görülmüştür ( $\left.R=.592 ; R^{2}=.350 ; \mathrm{p}<.000\right)$.

Adımsal regresyon analizinin ikinci adımında Problem Çözme Becerisinin yanına Özel Eğitim Süresi değişkeni de eklenmiştir. Modeldeki diğer değişkenler sabit tutulduğunda Problem Çözme Becerisinin ebeveynlerin yaşam doyumlarını yordama da ki beta katsayısı ,613 ; Özel Eğitim Süresi değişkenin yaşam doyumlarını yordama da ki beta katsayısı -,267 olup, beta katsayısının anlamlılı̆̆ına ilişkin $t$ testi sonuçları anlamlı bulunmuştur

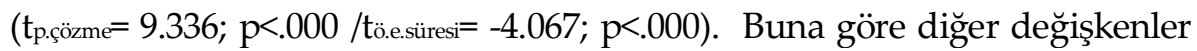
sabit tutulduğunda Problem Çözme Becerisinin ve Özel Eğitim Süresi değişkeninin ebeveynlerin yaşam doyumlarını yönelik tutumlarının $\% 42$ 'sini açıkladığı görülmüştür $\left(\mathrm{R}=.649 ; \mathrm{R}^{2}=.421 ; \mathrm{p}<.000\right)$. Adımsal regresyon analizinin üçüncü adımında Problem Çözme Becerisi, Özel Eğitim Süresi ve yanına Tanı Durumu değişkeni de eklenmiştir. Modeldeki diğer değişkenler sabit tutulduğunda Problem Çözme Becerisinin ebeveynlerin yaşam doyumların yordama da ki beta katsayısı ,598; Özel Eğitim Süresi değişkenin yaşam doyumlarını yordama da ki beta katsayısı -,284; Tanı Durumu değişkenin yaşam doyumlarını yordama da ki beta katsayısı,194 olup,beta katsayısının anlamlıl1ğına ilişkin $\mathrm{t}$ testi sonuçları anlamlı bulunmuştur ( $\mathrm{t}_{\text {.ç̆żme }}=9.339 ; \mathrm{p}<.000$ /tö.e.süresi $=-4.433 ; p<.000 /$ tanddurumu $=3.027 ; p<.05)$. Buna göre diğer değişkenler sabit tutulduğunda Problem Çözme Becerisi, Özel Eğitim Süresi ve Tanı Durumu değişkeninin ebeveynlerin yaşam doyumlarını yönelik tutumlarının \% 45 'ini açıkladığ1 görülmüştür $\left(R=.677 ; R^{2}=.458 ; \mathrm{p}<.000\right)$.

Standardize edilmiş regresyon katsayısına göre, $(\beta)$ zihinsel yetersizliği olan çocuğa sahip ebeveynlerin yaşam doyumunu yordayan değişkenlerin göreli önem sırası; problem çözme becerisi, çocuğun aldığı özel eğitim süresi ve çocuğun tanı durumu durumudur.

\section{Tartışma ve Sonuç}

\section{Zihinsel Yetersizliği Olan Çocuğa Sahip Ebeveynlerin Yaşam Doyumu ve Problem Çözme Becerisi Arasındaki İlişkiye İlişkin Sonuç ve Tartışma:}

$\mathrm{Bu}$ araştırma sonucunda ulaşılan ilk bulguya göre zihinsel yetersizliği olan çocuğa sahip ebeveynlerin yaşam doyumu ile problem çözme becerisi ara- 
sında anlamlı ilişki olduğu ve korelasyon değerlerinin pozitif yönde orta düzeyde olduğu tespit edilmiştir. Yaşam doyumunun problem çözme becerileri ile birlikte doğrudan ele alındığı bir araştırmaya yurt içi ve yurt dışı alan yazında rastlanmamıştır. Bu iki kavramı dolaylı olarak inceleyen çalışmalara bakıldığında ailede engelli bir çocuğun olması, engeli ne olursa olsun bazı özel güçlükleri de beraberinde getirdiği, ailelerin yaşadığı bu güçlükler; psikolojik, ekonomik, eğitimsel, yaşam tarzı, aile çevresi ve sosyal çevre ile ilişkiler ve çocuğun tanı durumundan kaynaklanabildiği görülmektedir (Işıkhan, 2005). Bununla birlikte Okanlı ve arkadaşları (2004) zihinsel yetersizliği olan çocuğa sahip ebeveynlerin çeşitli düzeylerde kaygı, depresyon, düşük özsaygıya sahip oldukları, engellenmişlik hissi yaşadıkları ve şahsi doyumlarının düşük olduğunu belirtmişlerdir. Yapılan çalışmalara bakıldığında ebeveynlerin problem çözme becerisini geliştirerek ailenin yaşadığı güçlükler karşısında onların daha kolay çözüme ulaşmalarının sağlanabileceği söylenebilir. Ayrıca ebeveynlerin problem çözme becerisini geliştirerek kaygı ve depresyon durumları ile de baş etmelerini kolaylaştırıp bu sayede yaşam doyumlarının arttırılabileceği düşünülmektedir.

\section{Zihinsel Yetersizliği Olan Çocuğa Sahip Ebeveynlerin Cinsiyetlerine Göre Yaşam Doyumu ve Problem Çözme Becerisine İlişkin Sonuç ve Tartışma:}

Araştırmada ikinci olarak cinsiyet değişkenine göre yaşam doyumunda manidar bir farklılık olduğu tespit edilmiştir. Cinsiyet değişkenine bağlı olarak yaşam doyumu açısından erkeklerin ortalama puanlarının, kadınların ortalama puanlarından anlamlı biçimde farklılık gösterdiği saptanmıştır. Yaşam doyumu açısından erkeklerin lehine bir farklılık bulunmaktadır. Buna karşın cinsiyet değişkeni ile problem çözme becerileri arasında manidar bir farklılık bulgulanmamıştır. Ebeveynlerin cinsiyetlerine göre yaşam doyumu ile problem çözme becerisi arasındaki ilişki alan yazında incelendiğinde farklı sonuçlar görülmüştür. Yaşam doyumu değişkeninin cinsiyete göre farklılaştı̆̆ını gösteren sonuçların yanı sıra (Akarsu, 2014, Kaner, 2004), farklılaşmadı̆̆ını (Lavallee, Hatch, Michalos ve McKinley, 2007, Arslan, Hamarta ve Deniz, 2002) gösteren bulgular da saptanmıştır. Benzer durum problem çözme kavramı için de geçerlidir. Problem çözme becerisinin cinsiyete göre farklılaşmadığını gösteren sonuçlar olmakla birlikte (Vatan, Dağ 2009, Tavlı, 2009, Güner, 2006), farklılaştığını (Serin, 2010) gösteren sonuçlar da bulunmaktadır. 
Bu bağlamda, aile içindeki roller dikkate alındığında genellikle söz konusu bakım yükünün daha çok annelerde olduğu söylenebilir. Zihinsel yetersizliği olan çocuğa sahip olmak; annelerin enerjilerini tüketmesi, kendilerine ayıracak boş zamanının kalmaması ve evde sürekli iş gören kişiler haline gelmeleri gibi nedenlerle yaşamlarında önemli bir etkiye sahip olabilir (Duygun, 2001). Dolayısıyla zihinsel yetersizliği olan çocuğa sahip annelerin babalara göre yaşam doyumu puanlarının daha düşük olması beklenebilir.

Problem çözme becerisi ve cinsiyet değişkeni arasında manidar bir farkl1lık bulunmamıştır. Günümüzde kadınlar günlük hayatın içerisinde daha fazla yer almaktadırlar (Kaya, 2014). Bu durumun da kadınların problem çözme becerilerini olumlu yönde etkilediği düşünülmektedir.

\section{Zihinsel Yetersizliği Olan Çocuğa Sahip Ebeveynlerin Yaşlarma Göre Yaşam Doyumu ve Problem Çözme Becerisine İlişkin Sonuç ve Tartışma:}

Yaş değişkeninin yaşam doyumu ve problem çözme becerisi ile ilişkisi alan yazında farklı sonuçlarla yer bulmuştur. Yaşam doyumunun yaş değişkenine göre farklılaştığını gösteren sonuçlar olmakla birlikte (Kavas, 2013, Çelik, 2017), farklılaşmadığını (Taş, 2011) gösteren sonuçlarda vardır. Problem çözme kavramında ise ebeveynlerin yaşına göre problem çözme becerilerinin hem farklılaştığını (D'Zurilla ve ark, 1998, MacPherson, 2002) hem de farkl1laşmadığı (Kaya, 2014, Demirkıran,2017) sonuçlara rastlanmıştır.

Örneğin, D’Zurilla ve arkadaşları (1998), problem çözme becerisinin yaş ilerledikçe artış gösterdiğini, 60 yaşından sonra ise tekrar düşmeye başladığını ifade etmişlerdir. MacPherson (2002) da, 30 yaşın üstündeki bireylerin problem çözme becerilerinin 30 yaşın altındakilere göre daha yüksek olduğunu belirtmiştir.

Bu çalışmada elde edilen yaşam doyumu ve problem çözme becerisi ile yaş değişkeni arasında manidar bir farklılık olmaması sonucunun olası nedenleri arasında ebeveynlerin çocukları küçük yaşlarda iken az olan beklentilerin çocukları büyüdükçe artması ve bu süreçte zihinsel yetersizliği olan çocukları ile normal yaşıtları arasındaki farkın büyümesi, çocuklarındaki problemlerin eğitimle ortadan kalkmadığını görmeleri ve ebeveynler ve çocukları yaş aldıkça uygun eğitim kurumlarının ve sosyal servislerin yetersizliği gibi durumlar gösterilebilir (Akıncı Aydoğan, 1999). 
Zihinsel Yetersizliği Olan Çocuğa Sahip Ebeveynlerin Yaşam Doyumu ve Problem Çözme Becerisinin Çocuğunun Tanı Durumu (Hafif, Orta, Ağır, Çok A ğır) Açısından Farklılaşmasına İlişkin Sonuç ve Tartışma:

Araştırma sonucunda ulaşılan bir diğer bulguya göre çocuğun tanı durumu değişkenine bağlı olarak ebeveynlerin yaşam doyumu ve problem çözme becerilerinin anlamlı bir farklılık gösterdiği tespit edilmiştir.

Zihinsel yetersizliği olan çocuğa sahip ebeveynlerin yaşam doyumuyla ilgili yapılan kıyaslamalar sonucunda tanı durumlarında (hafif, ağır, çok ağır) zihinsel yetersizliği olan çocuğa sahip aileler arasında hafif zihinsel yetersizliği olan çocuğa sahip aileler lehine anlamlı farklılık bulgulanmıştır. Orta ve çok ağır düzey zihinsel yetersizliği olan çocuğa sahip aileler arasında ise orta düzeyde zihinsel yetersizliği olan çocuğa sahip aileler lehine anlamlı farklılık olduğu görülmüştür.

Zihinsel yetersizliği olan çocuğa sahip ebeveynlerin problem çözme becerileriyle ilgili yapılan kıyaslamalarda ise çok ağır düzey zihinsel yetersizliği olan çocuğa sahip ailelerle, hafif, orta ve ağır düzeyde zihinsel yetersizliği olan çocuğa sahip aileler arasında; hafif, orta ve ağır düzeyde tanısı olan çocuğa sahip aileler lehine anlamlı farklılık belirlenmiştir.

Zihinsel yetersizliği olan çocuğa sahip ebeveynlerin çocuklarının tanı durumuna göre yaşam doyumu ile problem çözme becerisi arasındaki ilişkiyi inceleyen araştırmalarda farklı sonuçlar elde edildiği görülmektedir. Yaşam doyumunun çocuklarının tanı durumuna göre hem farklılaştı̆̆ını (Akarsu 2014) hem de farklılaşmadığını (Sarıkaya, 2011) gösteren çalışmalar bulunmaktadır. Sarıkaya' nın (2011) çocukların engellilik düzeyine göre ebeveynlerin stresle başa çıkma düzeylerinin farklılık gösterdiği bir çalışmasına rastlansa da farklılık göstermediği herhangi bir çalışmaya alan yazında rastlanmamıştır.

Araştırmada yaşam doyumu ve problem çözme becerisi ile çocuğun tanı durumu değişkeni arasında da manidar bir farklılık tespit edilmiştir. Arman (2009) tarafından yapılan çalışmada, çocuğun zihinsel yetersizlik düzeyi arttıkça ailelerin, duygusal tükenmişlikleri ve duyarsızlaşma durumlarının arttığını tespit edilmiştir. Ayrıca çocuğun zihinsel yetersizlik düzeyi arttıkça ailelerin problem çözme becerilerinde azalma meydana gelebileceği bunun yanı sıra çocuğun zihinsel yetersizlik düzeyinin daha az olmasının ailelerin çocuklara dair iyileşme beklentilerini arttırabileceğinden ötürü bu durumun 
ebeveynlerin problem becerilerinde etkili olabileceği düşünülmektedir. Bu bağlamda zihinsel yetersizlik düzeyindeki azalmanın ebeveynlerin, yaşam doyumu ve problem çözme becerilerini arttırması beklenmektedir.

\section{Zihinsel Yetersizliği Olan Çocuğun Birden Fazla Engelinin Olması Duru- muna Göre Ebeveynlerinin Yaşam Doyumu ve Problem Çözme Becerisine İlişkin Sonuç ve Tartışma:}

Araştırmada elde edilen diğer bir sonuç birden fazla engeli olan ve olmayan çocuğa sahip ebeveynlerin yaşam doyumu ve problem çözme becerilerinin puan ortalamaları arasında anlamlı farklılık bulunmamasıdır.

Çocuğun engel sayısındaki artıs ailelerin karşılaştıkları problemlerin artmasına ve bu problemlerin üstesinden gelmelerinin zorlaşmasına neden olmaktadır (Acar, 2009). Bu araştırmada, zihinsel yetersizliği olan çocuğa sahip ebeveynlerin yaşam doyumu ve problem çözme becerisinin çocuğun başka bir engel durumunun olup olması durumunda değişmesi beklenmiştir. Ancak elde edilen bulgular bu varsayımı desteklememiştir. Bunun nedenleri arasında gruplar arası dağılımın eşit olmaması gösterilebilir. Elde edilen bu sonuç doğrultusunda ailenin birden fazla engeli olan çocuğa sahip olması durumunun yaşadıkları sorunların çeşitliliği bakımından onların tecrübelerini arttırabileceği ve bununda sorunlar karşısında gösterdikleri dirence katkı sağlayabileceği düşünülmektedir. Nitekim ilgili alanyazın incelendiğinde her iki değişkenin de beraber ele alındığı yeterli sayıda çalışmaya rastlanmamıştır. Birden fazla engeli olan çocuğa sahip ailelere yönelik çalışmaların arttırılmasının alan yazına katkı sağlayacağı düşünülmektedir.

Zihinsel Yetersizliği Olan Çocuğun Aldiğı Özel Eğitim Süresine Göre Ebeveynlerinin Yaşam Doyumu ve Problem Çözme Becerisine İlişkin Sonuç ve Tartışma:

Zihinsel yetersizliği olan çocuğa sahip ebeveynlerin yaşam doyumlarının çocuklarının özel eğitim süresine göre farklılaştığı bu araştırmadan elde edilen diğer bir sonuçtur. Yapılan kıyaslamalarda; 3 yıl altı özel eğitim almış çocukların ebeveynleri ile 3- 7 yıl ve 7 yıl üstü özel eğitim almış çocukların ebeveynleri arasında 3- 7 yıl ve 7 yıl üstü özel eğitim almış çocukların ebeveynleri lehine anlamlı farklılık belirlenmiştir. 
Zihinsel yetersizliği olan çocuğa sahip ebeveynlerin çocuklarının aldığ1 özel eğitim süresine göre yaşam doyumları ve problem çözme becerileri değişkenlerinin ele alındığı araştırmalarda farklı sonuçlar görülmektedir. Örneğin, yaşam doyumu değişkeninin çocuğun aldığ hem farklılaştığı (Akıncı Aydoğan, 1999), hem de farklılaşmadığı (Acar, 2009) sonuçlar bulunmuştur.

Problem çözme değişkenine bakıldığında ise Demirkıran (2017) tarafından yapılan çalışmada çocuklarının özel eğitim alma süresinin problem çözme becerisi üzerinde anlamlı bir farklılık oluşturduğu tespit edilmişken Konukbay' in (2005) çalışmasında çocukların özel eğitim süresindeki artısıın ebeveynlerin problem çözme becerileri üzerinde anlamlı bir farklılık oluşturmadığı görülmüsstür.

Bir bakıma zihinsel yetersizliği olan çocuğa sahip ebeveynler, çocukları özel eğitim aldıkları müddetçe onlara karşı yaklaşımları konusunda bir eğitime dâhil olurlar denilebilir. Ebeveynler çocuklarının eğitimlerine karar verme, eğitim masraflarını üstlenme ve çocuklarının hak ve sorumluluklarına dair daha bilinçli olmayı öğrenebilirler. Bu sayede çocuklarına yardımcı olduklarını düşünen ebeveynler psikolojik olarak daha iyi hissederler (Özgür ve Zan, 2004). Dolayısıyla aile üyelerinin aralıklarla bir araya gelerek kendilerine ve çocuklarına ilişkin duygu ve düşüncelerini paylaşmaları onların yaşam doyumlarını artabilir.

Diğer taraftan bu araştırmada elde edilen zihinsel yetersizliği olan çocuğa sahip ebeveynlerin problem çözme becerilerinin çocuğun aldığ süresine göre manidar bir farklılık göstermemesi sonucuna dair olası nedenler arasında, ebeveynlerin çocuklarının eğitim aldıkları süreçte kendi uyumları içinde bir gelişme sağlayabilecekleri ve çocuklarını bu süreçte daha iyi tanıyarak yaşanılan sorunlara dair uygun çözümlere ulaşabilecekleri düşünülmektedir. Çocukların aldıkları eğitimin ebeveynlerin beklentilerini karşılamadığı ve aldıkları eğitimin süresinin uzadığı durumlarda; ebeveynler olumsuz duygularla daha çok karşı karşıya kalabilmektedir (Acar, 2009).

\section{Ebeveynlerin Eğitim Düzeyine Göre Yaşam Doyumu ve Problem Çözme Be- cerisine İlişkin Sonuç ve Tartışma:}

Çalışmanın diğer bir sonucuna göre ebeveynlerin yaşam doyumları ve problem çözme becerileri ile eğitim düzeyleri arasında anlamlı bir farklılık yoktur. 
Bu sonuç Balkan (2008), tarafından gerçekleştirilen araştırma sonucu ile paraleldir. Benze şekilde Taş (2011), eğitim düzeyi değişkenine göre yaşam doyum düzeyleri arasında anlamlı fark olmadığını bulgulamıştır. Öte yandan Akandere (2009), yetersizliği olan çocuğa sahip ebeveynler üzerinde gerçekleştirmiş olduğu çalışmasında eğitim düzeyinin yaşam doyumu üzerinde olumlu etkisi olduğunu gözlemlemiştir.

Problem çözme kavramına bakıldığında ise annelerin eğitim düzeylerinin problem çözme becerileri üzerinde etkili olduğu sonucuna ulaşılmıştır (Ayyıldız ve diğg., 2012). Ayrıca Quine ve Pahl (1991) yapmış oldukları araştırmada eğitim düzeyi yüksek olan anne-babaların problem çözme becerilerinin daha iyi olduğunu tespit etmişlerdir. Öte yandan Kaya (2014) tarafından yapılan çalışmada da ebeveynlerin eğitim düzeyinin problem çözme becerileri üzerinde etkisi olmadığı görülmüştür.

Günümüzde eğitimden beklenen, demokratik, yaratıcl, üretici, eleştirel ve çok yönlü düşünebilen, öğrenmeyi öğrenen, problem çözebilen, insanlara saygılı ve düşüncelere hoşgörü ile bakabilen sorumluluk sahibi bireyler yetiştirmektir (Tümkaya, Aybek, Aldaş 2009). Bu bağlamda eğitimin, problem çözme becerilerine olumlu yönde katkı sağlaması beklenen bir sonuçtur. Stein ve Book (2003) problemlerinin üstesinden gelebilen ve etkili çözümler üretebilen eğitimli bireylerin, yaşamda meydana gelen olaylar karşında uyum yeteneklerininin yüksek olması ve esnek davranışlar gösterebilmeleri sayesinde yaşam doyumlarının da yüksek olacağını belirtilmektedirler.

Buna karşın bu araştırmada zihinsel yetersizliği olan çocuğa sahip ebeveynlerin yaşam doyumu ve problem çözme becerilerinin eğitim düzeyi değişkenine göre anlamlı bir farklılık göstermemesinin olası nedenleri arasında araştırma örnekleminde gruplar arası dağılımın eşit olmaması gösterilebilir.

\section{Zihinsel Yetersizliği Olan Çocuğa Sahip Ebeveynlerin Yaşam Doyumlarının Yordanmasına İlişkin Sonuç ve Tartışma:}

Bu araştırmada elden edilen sonuçlara göre zihinsel yetersizliği olan çocuğa sahip ebeveynlerin problem çözme becerileri, çocuklarının aldığı özel eğitim süresi ve çocuklarının tanı durumu; onların yaşam doyumlarını anlamlı bir düzeyde açıklamaktadır.

Yordayıcı değişkenlerin yaşam doyumu üzerindeki göreli önem sırası; problem çözme becerileri, çocuklarının aldığı özel eğitim süresi, çocuklarının 
tanı durumudur. Bu üç değişkenin yaşam doyumunun toplam varyansının \%49'unu açıkladığı görülmektedir.

Ailelerin zihinsel engelli bir çocuğa sahip olmaları nedeniyle yaşadıkları stresle başa çıkmada önemli etmenlerden biri krizi karşılamaya yönelik sahip oldukları iç ve dış kaynaklardır (Küçüker, 2001). Zihinsel yetersizliği olan çocukların aileleri yaşadıkları psikolojik açıdan zorlayıcı süreçlerde çocuklarının gelişimi, bakımı ve günlük yaşamlarını sürdürebilmeleri adına pek çok alanda sorunla karşılaşmaktadırlar. Ebeveynlerin bu problemlerin üstesinden gelebilmelerinin yaşam doyumlarını olumlu yönde etkileyebileceği düşünülmektedir. Söz konusu bu nedenden ötürü zihinsel yetersizliği olan çocuğa sahip ebeveynlerin farklı alanlardaki problem çözme becerileri yaşam doyumlarının bir yordayıcısı olabilir.

Bununla birlikte zihinsel yetersizliği olan çocuğa sahip ebeveynlerin çocuklarının aldıkları özel eğitim süresi değişkenine bakıldığında; çocukların aldıkları özel eğitim süresi boyunca ailelerinin onlara yardımcı olabildiklerini düşünmeleri psikolojik olarak onları rahatlatmaktadır (Özgür ve Zan, 2004). Bu durum çocukların aldığı özel eğitim süresi arttıkça ebeveynlerin yaşam doyumlarının da artmasında etkili olabilir. Ebeveynlerin çocuklarının tanı durumlarının kendi yaşam doyumlarına etkisine bakıldığında ise engel düzeyinin daha alt grupta olmasının, ailelerde çocuklarının iyileşme beklentisini arttırabileceği görülmüştür (Sarıkaya, 2011). Bu durum da zihinsel yetersizliği olan çocuğa sahip ebeveynlerin yaşam doyumlarının artmasında etkili olabilir. 


\title{
EXTENDED ABSTRACT
}

\section{Investigation Of Problem Solving Skills And Life Satisfaction Of Parents Having Children With Mental Retardation}

\author{
Feray Başgöze - Mücahit Kağan \\ Ministry of National Education, Erzincan Binali Yildırm University
}

The concept of disability is generally used for individuals whose physical characteristics and learning competencies differ according to normal (Yavuz, 2016). Disability is a condition that cannot be changed and is a permanent situation and one of the types of disability is mental disability (Çoban Esen, 2003). In the 2010 instruction of AZYED (American Association for Mental and Developmental Yeti Deficiencies), mental disability is defined as being used the term "Mental Yeti Deficiency". According to this definition, "Mental Yeti Deficiency is a deficiency beginning before the age of 18, characterized as significant limitations manifested in mental functions and conceptual, social, and practical adaptive skills (AAIDD, 2010)". All disability situations,including mental disability, concern not only the person with the disability, but also his or her family, living with him or her and finding the lowest common denominator (Yavuz, 2016). The special care needs of a child with a disability, the attitudes and judgments of society regarding the child's existing disability, the lack of an obvious moment and future situation of the child, and in addition, economic deficiencies are the constant source of stress for families (Kaldırım, 2010). In such conditions, the pain and helplessness that some parents feel when struggling with their situations can negatively affect the satisfaction they receive from life. As a matter of fact, in the literature, it was observed that the satisfaction that parents with children with mental disabilities receive from life can negatively affect this situation (Arman, 2009). Life satisfaction is a concept that expresses the individual's ideas that relate to his past life, current life and future life (Diener and Lucas, 1999). This concept is associated with various variables such as gender, age, educational level, emotional and social skills that a person has (Diener, 1984). One of the variables 
associated with life satisfaction may be the problem-solving ability that individuals have. Problem solving skills positively affect the social harmony and success in everyday life, which are the most important characteristics of individuals in dealing with their environment. Considering the impact of difficulties faced by parents with mentally deficient children throughout their life on their psychological health, identifying social and educational variables that may be associated with life satisfaction and problem-solving skills is the problem of this research. The main aim of this research is to determine the relationship between problem-solving skills and life satisfaction of parents with children with mental disabilities. In addition, these concepts have been studied in terms of gender, age, education level, child's diagnostic status, duration of special education, and whether there are multiple disabilities.

In this research, the model used is correlational survey method. Participants consist of 138 parents of children with mental disabilities who continue their education at Special Education Vocational Education and Special Education Business Practice schools in province of Erzincan in 2017-2018 academic year. Of these parents, 94 are women and 44 are men. The data is collected through "Personal İnformation Form" developed by the researcher of this research and "Life Satisfaction Scale" -5-point likert-type, consisting of 5 items- developed by Diener et al (1985) and adapted into Turkish by Dağl1 and Baysal (2016), and finally "Problem Solving Scale For Adults" 5-point likert-type consisting of 18 items developed by Dede and Yaman (2008). In the analysis process, when the normality assumptions are provided, parametric tests like Pearson Correlation Analysis, Independent Sample t Test and Regression Analysis have been used, otherwise nonparametric tests like Kruskal Wallis $\mathrm{H}$ and Mann Whitney U Test have been used.

In the results obtained from the analysis of the data in the study, firstly it has been determined that there is a positive and significant relationship between the life satisfaction and problem-solving skills of parents with children with mental disabilities.

It has been detected that life satisfaction and problem solving skills of parents with children with mental disabilities become different according to gender, diagnosis of their children and duration of special education that their children receive. However it has been detected that there is no significant relationship between some variables such as age, educational status, the child's 
multiple disabilities, as well as their life satisfaction, also their problem solving skills. In addition, problem solving skills, special education period and diagnosis of their children are significant predictors of life satisfaction of parents with children with mental disability.

These results from the study are limited only to the level of mental disability as a type of disability. Therefore, other types of disabilities (autism, hearing-impaired, visually impaired, down syndrome) that will predict parents ' life satisfaction and problem-solving skills can also be addressed in different scientific studies.

\section{Kaynakça / References}

Acar, M. (2009). Zihinsel ve fiziksel özürlü çocuğa sahip anne ve babalarm yaşam umutsuzluk düzeylerinin incelenmesi. Yüksek Lisans Tezi, Selçuk Üniversitesi Sağlık Bilimleri Enstitüsü, Konya.

Akandere, M., Acar, M. ve Baştuğ, G. (2009). Zihinsel ve fiziksel engelli çocuğa sahip anne ve babaların yaşam doyumu ve umutsuzluk düzeylerinin incelenmesi. Selçuk Üniversitesi Sosyal Bilimler Enstitüsü Dergisi, 22, 24-32.

Akarsu, Ö. (2014). Zihinsel Yetersiz çocuklarn aile yükü, özbakm becerileri, annelerinin yaşam doyumu ve etkileyen faktörler. Yüksek Lisans Tezi, Trakya Üniversitesi Sağlık Bilimleri Enstitüsü, Edirne.

Akıncı Aydoğan, A. (1999). Özürlü çocuğa sahip anne babaların umutsuzluk düzeylerinin belirlenmesi. Yayınlanmamış Doktora Tezi. Hacettepe Üniversitesi Sağlık Bilimleri Enstitüsü, Ankara.

Arman, N. (2009). Zihinsel engelli çocuğa sahip anne ve babalarm algladıkları sosyal destek düzeyleri ile tükenmişlik ve kaygr düzeylerinin incelenmesi. Yayınlanmamış Yüksek Lisans Tezi, Atatürk Üniversitesi Sosyal Bilimler Enstitüsü, Erzurum.

Ayyıldız, T., Konuk Şener, D., Kulakçı, H. ve Veren, F. (2012). Zihinsel engelli çocuğa sahip annelerin stresle baş etme yöntemlerinin değerlendirilmesi.

Balkanlı, N. (2008). Otistik çocuğu olan ve olmayan annelerde yaşam kalitesi, yaşam doyumu ve umutsuzluk düzeyleri arasındaki ilişkinin incelenmesi. Yüksek Lisans Tezi, Maltepe Üniversitesi Sosyal Bilimler Enstitüsü, İstanbul.

Büyüköztürk, Ş. (2012). Sosyal bilimler için veri analizi el kitabı. Ankara: Pegem Akademi Yayincllik.

Çelik, B. Ş. (2017). Zekâ geriliği olan çocuklarm annelerinin yaşam doyumu, tükenmişlik ve yalnızlı düzeylerinin incelenmesi. Yüksek Lisans Tezi, Beykent Üniversitesi Sosyal Bilimler Enstitüsü, İstanbul. 
Çoban Esen, E. (2003). Tibbi-eğitsel yaklaşımla zihinsel engel okyanusun knyısı. Nobel Basimevi: Ankara.

Çöl, G. (2006). .Güçlendirme algilarini etkileyen sosyal yapisal özelliklerin analizi. METU Studies in Development, 33(1), 63.

Dağlı, A., ve Baysal, N. (2016). Yaşam doyumu ölçeğinin Türkçeye uyarlanması: Geçerlik ve güvenirlik çalışması. Elektronik Sosyal Bilimler Dergisi, 15(59), 1250-1262.

Demirkıran, H. (2017). Engelli çocuğa sahip olan anneler ile engelli çocuğa sahip olmayan annelerin depresyon düzeyi ve problem çözme becerilerinin incelenmesi. Yayınlanmamış Yüksek Lisans Tezi, Arel Üniversitesi, İstanbul.

Deniz, M. E., Arslan, C., ve Hamarta, E. (2002). Lise öğrencilerinin problem çözme becerilerinin çeşitli değişkenler açısından incelenmesi. Kuram ve uygulamada eğitim yönetimi, 31(31), 374-389.

Diener, E. (1984). Subjective Well-being; The Science of Happiness and a Proposal for a National Index. Psychological Buletin, 3 (95), 542-575.

Diener, E. ve Lucas, R. E. (1999). Subjective well-being: Three decades of progress. Psychological Buletin, 2(125), 276.

Diener, E., Emmons, R. A., Larsen, R. J. ve Griffin, S. (1985). The Satisfaction with Life Scale. Journal of Personality Assessment, 1(49), 71-75.

Duygun, T. (2001). Zihinsel engelli ve sağllklı çocuk annelerinde stres belirtileri stresle başa çıma tarzlar ve algılanan sosyal desteğin tükenmişlik düzeyine olan etkisi. Yayınlanmamış Yüksek Lisans Tezi, Ankara Üniversitesi, Sosyal Bilimler Enstitüsü, Ankara.

D'zurilla, T.J., Maydeu-Olivares, A. ve Kant, G. L. (1998). Age and gender differences in social problem-solving ability. Personality and Individual Differences, 25 (2), 241-252.

Eripek, S. (1996). Zihinsel engelli çocuklar. Anadolu Üniversitesi Eğitim Fakültesi, Eskişehir.

EYDER. (2019). Engelsiz Yaşam Derneği 12.03.2019 tarihinde, https://ey-der.com/anasayfa/turkiye-ve- dunyada-engelliler ,2019 adresinden alındı.

Friel, J. C. ve Frıel,L. D., (2003). İyi ebeveynlerin yaptı̆̆ en kötü 7 Şey. (Tuğba Şahin, Çev.). İstanbul.

Işıkhan, V. (2005). Türkiye' de zihinsel yetersizliği olan çocuğa sahip annelerin sorunları. Hacettepe Üniversitesi Yaymnlarn, 16(2), 35-52.

Kaner, S. (2004). Engelli çocuklarn olan ana babalarn algiladiklarn stres, sosyal destek ve yaşam doyumlarmmn incelenmesi. Bilimsel Araştırma Projesi Kesin Raporu, Ankara Üniversitesi, Ankara. 
Karaçengel, F. J., (2007). Zihinsel yetersizliği olan çocuğa sahip anneler ile sağllkh çocuğa sahip annelerin atılganlık ve suçluluk-utanç düzeyleri açısından karşılaştırlması. Yayınlanmamış Yüksek Lisans Tezi, Maltepe Üniversitesi, Sosyal Bilimler Enstitüsü, İstanbul.

Karasar, N. (2009). Bilimsel araştırma yöntemleri. Nobel Yayınları, Ankara.

Kavas, E., (2013). Dini tutum-stresle başa çıma ilişkisi. Yayınlanmamış Doktora Tezi, Süleyman Demirel Üniversitesi Sosyal Bilimler Enstitüsü, Isparta.

Kaya, F. (2014). Zihinsel engelli çocuklara sahip ailelerde problem çözme ve dini başa çıkma. Doktora Tezi, Süleyman Demirel Üniversitesi Sosyal Bilimler Enstitüsü, Isparta.

Konukbay, D. (2005). Engelli çocuk ebeveynlerinin umutsuzluk düzeyleri ve problem çözme becerileri arasındaki ilişki. Yayınlanmamış Yüksek Lisans Tezi. Gülhane Askeri Tip Akademisi, Sağlık Bilimleri Enstitüsü, Ankara.

Küçüker, S. (2001). Erken eğitimin gelişimsel geriliği olan çocukların anne babalarının stres ve depresyon düzeyleri üzerindeki etkisinin incelenmesi. Özel Ĕgitim Dergisi, 3(1), 1-11.

Lavallee, L. F., Hatch, P. M., Michalos, A. C. ve McKinley, T. (2007). Development of the contentment with life assessment scale (CLAS): Using daily life experiences to verify levels of self-reported life satisfaction. Social Indicators Research, 83(2), 201-244.

Macpherson, K. (2002). Problem-solving ability and cognitive maturity in undergraduate students. Assessment \& Evaluation in Higher Education, 27 (1), 5-22.

Nazlı, S. (2001). Aile damışmanlığı. Nobel Yayınları: Ankara.

Okanll, A., Ekinci, M., Gözüağca, D. ve Sezgin, S. (2004). Zihinsel engelli çocuğa sahip ailelerin yaşadıkları psikososyal sorunlar. Uluslar arası İnsan Bilimleri Dergisi, $1,1-8$.

Özgür, İ. ve Zan, B. (2004). Engelli çocuk, engelli aile. Çukurova Üniversitesi Eğitim Fakültesi Dergisi, 2, 18-27.

Quine, L. ve Pahl, J. (1991). Stress and coping in mothers caring for a child with severe learning difficulties: A test of Lazarus' transactional model of coping. Journal of Community \& Applied Social Psychology, 1(1), 57-70.

Sarıkaya, S. (2011). Zihinsel engelli çocuğu olan ebeveynlerin stresle başa çıkma düzeylerinin ve yaşam doyumlarnnın incelenmesi. Yüksek Lisans Tezi, Dokuz Eylül Üniversitesi Eğitim Bilimleri Enstitüsü, İzmir. 
Schalock, R. L., Borthwick-Duffy, S. A., Bradley, V. J., Buntinx, W. H. E., Coulter, D. L., Craig, E. M., ... \& Reeve, A. American Association on Intellectual and Developmental Disabilities; (2010). Intellectual Disability: Definition, Classification, and Systems of Supports.

Serin, O. (2010). Sınıf öğretmenlerinin problem çözme becerilerinin çeşitli değişkenler açısından incelenmesi. Ĕ̆itim ve Bilim, 32(142).

Soden, R. ve Pithers, R.T. (2001). Knowledge matters in vocational problem-solving: A cognitiveview. Journal of Vocational Educationand Training, 53(2), 205-222.

Stein, J. S, Book H. E. (2003). EQ Duygusal Zekâ ve Başarmın Strrı. Özgür Yayınları: İstanbul.

Tabachnick, B. G. ve Fidell, L. S. (2013). Using multivariate statistics (6th ed.), Boston: Allyn and Bacon.

Taş, İ. (2011). Öğretmenlerde yaşamın anlamı yaşam doyumu sosyal karşlaştırma ve iç-dış kontrol odağının çeşitli değişkenler açısından incelenmesi. Yayımlanmamış Yüksek Lisans Tezi, Sakarya Üniversitesi, Sakarya.

Tümkaya, S., Aybek, B. ve Aldaş, H. (2009). An investigation of university students' critical thinking disposition and perceived problem solving skills. Eurasian Journal of Educational Research (EJER), (36).

Vatan, S., ve Dağ, İ. (2009). Problem çözme, umutsuzluk, çaresizlik ve talihsizlik MMPI-2 ile ölçülen psikopatolojinin yordayıcıları olabilir mi. Anadolu Psikiyatri Dergisi, 10, 187-197.

Yaman, S., ve Dede, Y. (2008). Yetişkinler İçin Problem Çözme Becerileri Ölçeği. Journal of Educational Sciences \& Practices, 7(14), 251-269.

Yavuz, S. (2016). Normal Gelişim Gösteren Çocuğa Sahip Ebeveynler Ille Zihinsel Yetersizliği Olan Çocuğa Sahip Ebeveynlerin Evlilik Uyumu ve Yaşam Doyumu Düzeylerinin İncelenmesi. Yüksek Lisans Tezi, Haliç Üniversitesi Sosyal Bilimler Enstitüsü, İstanbul.

\section{Kaynakça Bilgisi / Citation Information}

Başgöze, F. ve Kagan, M. (2020). Zihinsel yetersizliği olan çocuğa sahip ebeveynlerin problem çözme becerileri ile yaşam doyumlarının incelenmesi. OPUS-Uluslararası Toplum Araştırmaları Dergisi, 16(Eğitim ve Toplum Özel Say1s1), 5651-5680. DOI: 10.26466/opus.787019 